\title{
Is Corporate Communications A Strategic Function?
}

Management Decision (2000), 38:2, 99-106

\author{
Richard R. Dolphin* \\ Independent Consultant \\ Ying Fan \\ University of Hertfordshire Business School
}

\begin{abstract}
Corporate communications, or public relations (PR) as hitherto it has largely been known, has become an increasingly important function in business organisations. Yet little has been published on the role and function of communication executives. This paper reports an empirical study conducted in 20 British organisations with a focus on the director of corporate communications. It examines the role and tasks of corporate communication executives and discusses their status within organisational structure and the impact of corporate communications upon the strategic planning process.
\end{abstract}




\section{IS CORPORATE COMMUNICATIONS A STRATEGIC FUNCTION?}

\section{INTRODUCTION}

Academic literature refers to $P R$ and corporate communications in changing terminology. Similarly, emphasis of nomenclature varies with the country of origin. In the United Kingdom, but not in the United States, PR has become debased. What used to trade under the name of PR is now known variously as: corporate affairs, corporate communications, and public affairs. Correspondingly there are different job titles to the executives holding the office.

Over the past decade corporate communications has become recognised as one of the most valued strategic tools; yet it is among the most under-researched; as is the role of the director of corporate communications. Is his role strategic, for instance? It is under researched partly because, as Wright (1995) identified in American research, there are only a small number of what he refers to as communication executives in the US; they are busy individuals paid very large salaries and they are not noted for filling out questionnaires or otherwise participating in academic research.

Corporate communication has matured into a key discipline of enlightened and progressive management. It has to play a key role in the strategic planning of its organisation. There can be little debate that corporate reputation is now one of the critical issues. The corporate brand has become a key competitive weapon. This means that what was originally known as PR needs to be where it belongs - in, or very 
close to, the board room. This pilot study, which involved interviewing twenty very senior communication directors from British industry and the public sector, has attempted to explore the present impact on corporate strategy of the corporate communications process.

\section{LITERATURE REVIEW}

It is widely accepted that corporate communications has a crucial role to play in what Winner (1993) calls the total business system. However, there is still no universally accepted definition of the concept, for example, Harlow identified several hundred different definitions (quoted in Winner,1993). In this research, a working definition is given as follows:

Corporate communications is the strategic management process by which an organisation communicates with its various audiences to the mutual benefits of both and to its improved competitive advantage.

The role of the communications executive is still embryonic as an established function (White and Mazur,1995). It is misunderstood in many organisations. This makes the task less clear cut. Yet Moore et al (Quoted by Kitchen, 1993) suggest that it is one of the most essential. Its importance as an early warning system is beyond dispute (Lauzen,1995). However, empirical research into the work of the director of communications is painfully limited. Wright (1995) confirms this in producing his concept of the communications executive. His opinion was echoed by other authors: Broom et al (1986), Grunig (1992) and Pavlik (1996); and by the enquiries made by the authors to professional bodies, among whom were the Institute of Public Relations (UK), American Marketing Association and the Arthur Page Society (USA).

Academics seem to be undecided about what is expected of the PR directors. Howard (1992) likens the process of corporate communications to throwing a dart at a wall 
and then drawing a target around it. This suggests a dubitable role; and possible equivocation about what one ought to be doing. Ambiguity is as possible a source of anxiety and stress as being overloaded with work (Winner,1993). Some practitioners consider that communicating presents the very least of their problems (Simon, 1986). Jackson (1995) questions the role. There are a variety of different descriptions given to essentially the same task. All put different emphasis on much the same job. It is one that is much wider than what Grunig and Hunt (1984) identify as the press agentry model. It varies from organisation to organisation (Brody,1988; Guth,1995) and between different countries (Nessmann, 1995). Communication directors are not just drawing up advertisements and writing propaganda (Howard, 1992).

Bowman and Ellis (1969) propose that practitioners exist to create and foster relations between organisations and their publics. As Lauzen (1995) suggests they provide cultural cross-fertilisation with their publics and relay organisational values to and from their audiences. This might place the practitioner in an invidious position for he stands between the organisation and the world outside. While White and Mazur (1995) quoting Mann remark that organisations have to close the gap between what they say and the way the they behave.

Howard (1992) explores the wider aspects of the office. He suggests that the role of top communication executives in major organisations may be a mixture of various typologies: planner, watchdog, catalyst, communicator, savant, stimulant, advisor and confidant. He remarks that the director should be strongly aware of his organisation's corporate identity, corporate philosophy, style and structure. If the job specification is to be effective it must be generated in collaboration with the CEO and the corporate 
team. The nature of the role requires that the specifications are flexible, adaptable to changes and reviewed constantly. If strategy is one of communication or education he must develop messages that reflect the desired behaviours.

Two particular parameters face a communications director: a) the source of responsibility; b) to whom he reports. Nessmann (1995) states that European practitioners are still struggling to attain positions of management in many of their organisations. Pincus et al. (1994) comment on a belief commonly held among managers of how little they believe PR adds to corporate performance. Perhaps to function effectively the communications director should be aided by high visibility and status throughout his organisation. Is he a member of the dominant coalition? (Wright, 1995). IABC identify that effective practitioners are those who are part of their company's dominant coalition.

This raises the question of where he fits in the organisation's structure. Howard (1992) stresses how essential it is that the communications director reports direct to the $\mathrm{CEO}$; thus ensuring that the link with top management thinking is as close as possible. Bowman and Ellis (1969) confirm that the communications director should have a core role in the management structure. Their view is that the particular knowledge and skills of the practitioner justify his place at the decision making table. Lauzen (1995) suggests that the exclusion of practitioners from this decision-making process reduces corporate communications to a low category support function. Bowman and Ellis emphasise this by saying that if the executive is not himself a director then he should unquestionably report to one. A certain way of confirming the status of the practitioner is to note to whom he reports (Simon, 1986). 
The status may depend upon the organisation's own view of communications (Winner, 1993) and of other organisations in its sector. But, the executive must carry authority and in large organisations he must have a great deal of it. Lack of media credibility frequently arises because audiences are not satisfied that the spokesman is sufficiently part of the policy-making machine to be wholly credible (Howard, 1992). White and Mazur (1995) add that the communication executive must be listened to. Referring to Terrence Collis, they exemplify that he was one of the few senior communications officials who not only had clout, but was seen to have it. The organisation should look up to him as a man of wisdom. Organisations are beginning to understand that with so many social, political and ethical issues influencing their performance, responsible managers have no choice but to incorporate an awareness of public affairs into their daily management decisions. The confidence that should exist between the organisation and its communications director must be mutual. Certainly there are occasions when the company needs to seek the director's council as to how a delicate issue should be handled (Winner, 1993).

Although much has been written on the subject, no empirical research on the role and tasks of corporate communications has been found after an extensive research. This paper intends to address the balance and to improve the current understanding of the area in the British corporate context.

\section{METHODOLOGY}

This investigation probes previously unexplored territory with a focus on the communication director, his background and his training, It seeks to identify the 
characteristics frequently found in a practitioner at the top of his profession. The research attempts to discover whether he originates from the generalist route; whether he has a marketing or journalist background; and whether any organisations practice encroachment.*

It is beyond the scope of an individual study to test every diverse issue. In the remainder of the paper, the methods employed in the field work are first discussed. This is followed by the findings derived from the research. Finally there is a discussion of the theoretical and managerial implications of the findings as well as the suggestions for future research.

* Those not qualified or trained to do the job (Lauzen, 1995:288).

\section{The Sample}

24 organisations were approached through either personal contacts or direct written request. 21 agreed to participate in the research. Of them, eighteen were with key communication executives at the apex of British industry. To give the investigation some breadth, two were with PR managers in the public sector. These organisations were selected because they appealed to the researchers and came from a broad spectrum across the British industry. All of them are respected names in their own sectors and some of them large global organisations. It was not a random sample and therefore must not be relied upon as a source of statistical inference.

\section{The Survey}

Empirical investigation was divided into two stages - questionnaire survey and personal interview, and was carried out between June and August 1996. A 
questionnaire was developed consisting of total 50 questions in eight sections which aimed to find out how respondents felt about their job and its importance to their organisation. Areas explored include:

- the concept of corporate communications,

- $\quad$ the role and tasks of corporate communications, and particularly,

- $\quad$ the impact on strategic decision making,

- the status of the director within an organisation.

The questionnaire draft was tested with one organisation and subsequently revised three times. All questionnaires sent were returned and useable.

\section{Interviews}

The interviews were well prepared but each was conducted in an unstructured way, allowing the addition or deletion of some questions while at the same rapidly returning to the main topics under discussion. As Carter (1995) suggests, a conversational interview allows a greater depth of enquiry and response level than a more formalised interview. Anecdotal comments which added greatly to the conclusions are used when they are clearly reflective of a general view.

The interview took place at the corporate headquarters of each company visited and the researchers travelled more than 5,000 miles. A standard format was followed in each case and a specific time limit was agreed at the outset as was the question of attribution. The typical interview lasted 111 minutes (the range being from one to three hours). A written transcript was taken during the interview and analysed immediately afterwards. At the beginning of an interview, each interviewee was told that anything he said would be on the record and would not be treated as confidential 
unless the interviewer was instructed otherwise. Anything given off the record would not be reproduced. Some remarkable insights were offered into the problems of corporate affairs which affect major British companies but they will remain confidential. With one exception, these interviews proved to be exceedingly fruitful producing a rich harvest of data.

\section{FINDINGS}

\section{Tasks in Corporate Communications}

The small amount of existent research does not lead academics towards knowledge of what the corporate communications director does; for example, Guth wonders if the role varies between organisations. Nor does it indicate which precisely his audiences might be (or where they might be found). Beyond that the question arises as to whether the role has boundaries. If so who sets them and where they are located.

The authors' initial research shows that 10 percent of respondents believe that the role does vary between organisations; research confirms that this is certainly the case between public and private sectors. Contrariwise those interviewed confirmed in equal measures that cultural issues impact on the role; as does the influence of the CEO. However, 40 percent of interviewees felt that there were variations - but only of degree. In 95 percent of organisations interviewed the role was a full time job. There was agreement concerning both its diversity and range. A global drugs company referred to its almost unlimited potential and of the need to ensure consistency of the message to a wide range of audiences. 
One of Britain's largest brewers reported that a central plank of his function was advising executive colleagues on the impact of communications on the organisation's corporate reputation. A top British clearing bank saw the purpose of his job as advising his CEO on his company's direction. A regional brewer perceived his purpose to be that of raising the profile of others; whilst a brewer in the north east stressed that communication is itself both external and internal. Flexibility is a keynote as a major television station emphasised - the message may not be the same for two weeks running.

The location of the role was noted as being indicative of the importance placed upon good PR by an organisation. At the same time, in more traditional organisations, the role is muddled. London's major transport network could not identify a precise role at all. Britain's largest airline meanwhile perceived that an important part of his job is to convey his organisation's personality and position on various issues to all those audiences who might be placed to shape an opinion. He emphasised how important it is that the audiences of a major organisation feel comfortable with the organisation and what a key element it is of the function to see that this is achieved.

The researchers found that the role has few boundaries. 45 percent of the communications directors interviewed have complete autonomy; another 35 percent felt that such constraints that are imposed upon them are slight - not least because most report direct to their CEO. In some middle ranking companies the boundary line is that - as in the instance of a Scottish brewer - his group HQ (in his case at Burton on Trent) deals directly with some sensitive national brand issues. Due no doubt to the diversity of the role and to the ever widening audiences that are reached the 
researchers found an enthusiasm - perhaps even a joy - for the work amongst almost all those interviews. One communication director at an international tobacco giant spoke of the wonderful job; although he admitted that it can be tiresome. One illustration of the latter (given by the director of an award winning PR unit at a West Country constabulary) was the problem caused when the actions of her employees were in direct conflict with her advice. As a result she was often subsequently left with the task of picking up the resulting PR pieces.

\section{Is the Role Strategic?}

The small amount of existing academic work does not suggest what role the director of corporate communications plays in the forming of strategic policy within his organisation. In fact, is his role strategic? One national newspaper retailer commented that in the past his organisation had avoided talking to the press. They had a bunker mentality. Now under new management - and with a new corporate strategy - all that had changed. 85 percent of respondents told the interviewers that they definitely considered the potential impact of the decisions made by their organisations on their audiences. But, what part does the director play in this process? A high street retail chain concluded that in the broadest sense his company considered PR to be an important element all their decisions. Regarding budgets, for instance, he opined that his company considered how the City (an important audience for them) would view them.

The researchers note that some national organisations have strategic planning committees. Some of these committees have a PR presence on them. Some do not - an international tobacco firm is an example. However, their director understands the 
arguments that are going through the committee. Contrariwise, one of our leading brewers has a Strategic Communications Committee, their director (at the highest ranking executive level found in the survey) does sit on that. This committee was described as a driving force; there the executives talk about the perceptions of their various audiences. The committee understands the messages because it helps to shape them. 80 percent of those interviewed confirmed that they were involved in shaping corporate identity: on the other hand 15 percent said that they were not involved at all. One leading rubber company admitted that his company had spent no money on promotion for twenty years; indeed he acknowledged that his senior management had little understanding of - or sympathy for - the benefits that might accrue from strategic corporate communications. Presumably none of them had recently gained an MBA from a leading business school!

Further, a nationally respected bank acknowledged that its Group had no overall PR strategy. In its organisation the PR view was largely that of the CEO - who happened to be a very powerful figure. The researchers' impression was of a communications executive who largely practised a communications policy produced from day to day at the whim and fancy of the CEO. Certainly, the practitioner admitted that he had to carry out policies which were, at times, a headache to him (e.g. Third World Debt). At Britain's second ranking supermarket chain, where the family ethos was self-evident, it was clear that communication direction came from the board - the board decides the level of input. Clearly policy did not originate in the PR department. As the board had no representative with knowledge or experience of communications this struck the researchers as remarkable. 
At a national retailer the executive has a say in developing policies; but he does not sit on the board and only handles Financial PR - the value of that input might be limited. At a global drugs firm the director reports only to the CEO. That mechanism permits input direct to the strategic forming process.

Some major organisations have a sharply defined perception of PR from the very top. The chairman of the world's favourite airline has strongly developed PR skills himself. As a result his organisation's communications strategy is developed at the very summit of the organisation. It is visibly strongly led. There the authors were told that their PR played an enormous part in corporate strategy because everything the organisation did had a huge impact on the public. They expect to recognise the PR aspects of any proposed move - for PR should provide the early warning system. A far cry from the rubber company - whose management doubt the value of PR!

A west country water provider summed it up the best saying that PR in its broadest sense is an integral part of running the business. They consider PR in everything that they do. An interesting comparison with a northern supermarket who regard PR as very important - but only have one official handling it - at a minor level.

\section{Image Creation / the Alter Ego}

Van Riel (1992) remarked that communication activities are aimed at improving the image of an organisation. So, is the communications executive an image creator as Howard2 suggests? Is he shaping - or helping to shape - corporate identity? Indeed, does he represent the face of the organisation? 
The researchers found a sharp division of opinion regarding the matter of image. Half considered themselves image creators; 40 percent of them definitely did not do so. Some interviewees, perhaps more concerned with substance than style, viewed image creation in a negative way. The executive at a global tobacco company sees himself as a reputation engineer; whilst a significant Scottish brewer considers image creation as the essence of the art. Perhaps the communication director of a national retail chain summarised it most clearly when he opined that he is not in the business of creating a reputation that cannot be sustained.

Interestingly, the 50 percent who said that they helped to create images expressed strong views regarding what an important part of their job it is; indicating that it is what they do totally and that it is a prime function of their department. Image creation leads to the subject of corporate identity. 95 percent of those interviewed associated their job with helping to shape corporate identity -80 percent considered it a totality of their job. The five percent who disagreed considered themselves as projectors of the role rather than creators of it.

Whether creating an image or corporate identity the communication director is inevitably projecting himself; or is he? Perhaps he is faceless? Howard3 conceptualised the PR director as the alter ego of his corporation. This research does not sustain this concept. 80 percent of those interviewed rejected the concept that they might be the face of their organisation. But, it has to be remarked that the 15 percent who agreed with it did so vociferously and without qualms. The findings of the paper to hand are that it is the CEO or Chairman - the Richard Bransons or the Lord Kings who are the face of their organisations. 
At one extreme a west country water company declared that she did not agree with the principal. A northern brewer declared that she would not be so arrogant. A Scottish brewer announced clearly that his CEO was the Scottish face of his organisation; whilst the executive at a national brewer dismissed the concept as one emerging from spin doctoring and went on that the whole idea was a con. A director of a global drug company added that the idea was a worn out perspective. Those directors saw their role as promoting their CEO or Chairman. The PR practitioner at the constabulary saw her role as projecting the Chief Constable - a reassuring figure in uniform whilst a television company executive told how he was keen to get the CEO out there. Another northern director spoke of how she fought against the concept of a personality based company. A national supermarket declared that it was the family whose name the chain bears who is the alter ego.

However, the largest supplier of telecommunication services acknowledged the concept by saying that he represented the desired character of his organisation, whilst a rubber company admitted that there was an issue of corporate personality - which he represented. The three directors who cheerfully agreed with the idea did so strongly. A tobacco chief said that it was his perception of the role; that he enjoyed standing up for his company and handling the difficult issues as its spokesmen. A retail chemist spokesman said the same thing; opining that only one person could stand up for any organisation.

\section{DISCUSSION}

The findings suggest that the communications director plays an increasing role in the formulation of corporate strategy. Few today pursue a bunker mentality (although 
remarkably some still do). But, the executives input could - and should - be greater and at a higher level. Few (but some!) organisations of any size are unaware of the importance of PR; many are more aware than others. The conclusion also is that the more traditional an organisation - and the less it has changed its structures - the less likely it is to make full use of the powers that good communications are ready to unleash.

The researchers found evidence of Strategic Committees at the top of British industry (with no communications executives sitting on them - although they are able to input to them) and in some cases Strategic Communications Committees. Only one top executive was found on one of them - in spite of the fact that such a committee was described as a driving force. Influential executives demonstrate remarkable clarity of strategic intent not least because a majority of them acknowledge that they are involved in shaping corporate identity. It is confirmed that one objective is to bolster a rising share price; other objectives are excellent relations with opinion formers and a better understanding of the corporation by their various audiences.

It is interesting to make the comparison between a major bank and a global airline. In the one the CEO has reservations about the strategic value of communications policy and largely develops it himself day by day. In the other the chairman has huge personal experience of PR and leads an enormous communications department with experience and by example. Again, in a national supermarket the PR lead comes from the board - where none of the necessary PR experience is present. Further, in at least one instance, although the communications director has a role in forming strategic plans his own remit is purely financial PR (with a little internal PR thrown in) so his input its necessarily narrow. 
At a time of change the role of the director is seen as more important than ever; embracing so many different management disciplines and playing, as it must, an integral role in corporate strategy. The role has widened. At the highest level the director plays a pivotal role with a wide range of audiences. A communications strategy is a first essential for any organisation. It needs to be formulated by the director in close conjunction with the $\mathrm{CEO}$ and the Executive Team (the more reason for his being part of it). When shaping strategy, consideration must be given to the nature of the organisation itself; to its mission and vision; and to its audiences.

In formulating strategy the director must have a profound holistic knowledge of his organisation. In turn the corporation as a whole must share a deep understanding of, and shared belief in, the essentiality of excellent communications. This study posits that the essentiality of the director's task is to act as a bridge between his organisation and its audiences. It is not dubitative that the developed role is focused on establishing an entente with those publics. The purpose of that relationship is to develop and enhance the reputation of the organisation itself.

So, in acting as a bridge, does the director create an image? The researchers found opinions among executives sharply divided; those in a narrow minority saw a negative aspect to the suggestion. Probably all interviewees would have agreed that an image that cannot be sustained is not something that they would wish to create. So they would agree that they perceive their role to be one of promoting that which can be sustained. All - of whatever persuasion - would be concerned about projecting the best that their organisations have to offer to their various audiences. 
The idea of corporate culture is a recent concept to students of management science but probably it is something that has always existed. Corporate identity does represent the corporate culture and all those interviewed see it as a critical part of their role to promote that corporate identity and they recognise its importance. But is the communications executive promoting himself?

A major finding is that communication executives most certainly do not regard themselves as their organisation's alter ego. Only three of those interviewed agree with this proposition (and one of those because of the specific issues associated with his doubly controversial industry saying we have two highly controversial businesses so $P R$ is very important. If anyone is so regarded, most interviewees perceive their CEO to be the alter ego (some CEOs are colourful individuals in their own right). One sees the family whose name the business carries as the face of her organisation. Two significant conclusions are drawn from these responses:

1. A family may be conceptualised as the face of an organisation (maybe an anachronism in 1997 - and possibly not a strength - it would depend upon the family).

2. Certain controversial areas require image bolstering and special presentational skills to aggrandise their level of acceptance to their various audiences.

\section{SUMMARY AND CONCLUSIONS}

This pilot study seeks to investigate a number of issues, the underlying difficulty being the absence of a sound theoretical base on which to ground deductive hypothesis. Accordingly the conclusions reached might be considered to be inductive. Twenty years ago the proposition that PR might play an essential part in corporate strategy would have been scorned; but possibly two decades ago some organisations did not 
have a corporate strategy. Today an essential discovery is the extent to which many corporations value the input into their strategic planning from corporate communicators. Most - but still not all - major organisations perceive the impact that communications have upon their audiences; although the researchers are surprised to find the number of major industrial figures who remain sceptics. However, the authors sense that the value of executives' input would be enhanced if they sat on their Executive Committees and, thus, were able to input at first hand. In fact only one individual spoken to had a place on his strategic communications committee.

The conclusion is confirmed in the authors' minds by the fact that most of those interviewed displayed considerable knowledge of - and aptitude for - an understanding of the importance of communications strategy; many being concerned with bolstering their share price or informing their colleagues. Just as interesting was the heavy hand used by some major CEOs in forming their own strategy very much on the hoof: interesting also was the imposition of PR policy on the PR people from board level in a major supermarket.

The authors noted the considerable and beneficial impact on one major corporation of communications policy from one chairman - himself a master of the craft. The inescapable view was that at the highest level the role of the communications executive has changed out of all recognition and that he now helps to play a role aimed at very many different audiences and that, together with his senior colleagues, he has a great responsibility for the formation and implementation of agreed strategies. 
The researchers noted that in forming this bridge with his publics the director helps either to create or to sustain an image. The researchers were interested in the conflict of views on the question of image creation but felt that at heart probably both views merged somewhat. The essentiality was probably made plain in the view expressed by a major chemist that it was not his business to create or develop an image that could not be sustained. Almost all those interviewed were enthusiastic about promoting their organisations' corporate identity and most recognised the growing significance of corporate culture. The authors were interested in the extent to which respondents felt strongly that they were not the face of their companies but observed the strength with which three directors felt that was there role - two of whom were very senior figures indeed. The finding of this paper is that the communication executive sees it as his role to raise the profile of his CEO - not of himself.

Corporate communications is rapidly becoming a senior discipline. It cries out for further research in a number of areas. The impact of excellent communications and their effect on strategic processes is one; the role that it plays in developing and promoting corporate image and identity is unquestionably another.

\section{Limitations}

The method employed in this research was proved to be quite effective, evidenced by the fact that 88 percent of organisations contacted participated in the survey and interview, 62 percent of interviewees gave more than two hours of their time, and one third asked to see the results. Due to time and finance constraints, it would have been impossible to visit a larger sample spread across the length and breadth of the UK. It was felt that a small sample thus served best, as American research has shown that a 
larger number of questionnaires would not have been likely to have been returned and, invaluable though the data accumulated by this means was, the great bulk of the research material accumulated came from the interview technique and the ability to ask supplementary questions at several levels.

There were few problems. Appointments were easily made with senior officials who were willing to co-operate and who displayed great interest in the work being done. Had time and financial resources allowed a sample 50 percent larger would have undoubtedly given greater breadth to the sample being investigated. 


\section{REFERENCES}

Bowman, P and Ellis, N (1969) Manual of Public Relations, Heinemann, London

Broom, G M and Dozier, D M (1986) Advancement for public relations role models, Public Relations Review, vol 12 37-56

Grunig, L A (1992) Strategic public relations constituencies on a global scale, Public Relations Review, vol. 18, 127-136

Grunig, L A and Hunt, T.T, (1984) Managing Public Relations, CBS College Publishing, N.Y. p21

Guth, D W (1995) Organizational crisis experience and public relations roles, Public Relations Review, vol. 21, 123-136

Howard, W (1992) (ed), The Practice of Public Relations, Butterworth-Heinemann, Oxford

Jackson, M (1995) Public relations -getting it right, Learned Publishing, vol. 8, 151157

Kitchen, P (1993) Public relations: a rationale for it development and usage within

UK fast-moving consumer goods firms, European Journal of Marketing, vol.27, 53-75

Lauzen, M M (1995) Public relations manager involvement in strategic issue diagnosis, $\quad$ Public Relations Review, vol. 21, 287-304

Nessman, K (1995) Public relations in Europe: a comparison with the United States, Public Relations Review, vol. 21, 151-160

Pavlik, J V (1996) Review of Corporate Public Relations, Public Relations Review, vol. 22, p58

Pincus, J D et, al. (1994) Public relations in MBA programme: challenges and opportunities, California State University, vol. 20

Simon, R (1986) Public Relations Concepts and Practices, McMillan, New York

Van Riel, C B M (1992) Corporate communication in European financial institutions, Public Relations Review, vol. 18, 161-175

White, J and Mazur, L (1995) Strategic Communications Management, AddisonWesleym Wokingham, UK

Winner, P (1993) Effective Public Relations Management, Kogan Page, London

Wright, D K (1995) The role of corporate public relations executives in the future of employee communications, Public Relations Review, vol. 21, 181-198 
Table 1 The list of respondents and their titles.

\begin{tabular}{|c|c|}
\hline THE ORGANISATION & THE RESPONDENT \\
\hline ASDA Plc & Director of Corporate Communications \\
\hline Avon Rubber Plc & Group Publicity Manager \\
\hline Avon \& Somerset Constabulary & Public Relations Manager \\
\hline B.A.T. Industries Plc & Director of Group Public Affairs \\
\hline Boots Group Plc & Director of Corporate Affairs \\
\hline British Airways Plc & Director of Public Affairs \\
\hline British Telecommunications Plc & Director of Corporate Communications \\
\hline GlaxoWellcome Plc & Director of Group Public Affairs \\
\hline Lloyds TSB Plc & Head of Corporate Communications \\
\hline London Transport & Head of Corporate Affairs \\
\hline Northumbria Ambulance NHS Trust & Public Relations \& Marketing Manager \\
\hline J. Sainsbury Plc & Director of Corporate Communications \\
\hline W. H. Smith Group Plc & Director of Corporate Affairs \\
\hline Southwestern Electricity Plc & Director of External Affairs \\
\hline Storehouse Plc & Director of Corporate Affairs \\
\hline Tennent Caledonian Breweries Ltd & Communications Manager \\
\hline Vaux Group Plc & Director of Group Public Relations \\
\hline Wessex Water Plc & Director of Corporate Communications \\
\hline Whitbread Plc & Director of Corporate Communications \\
\hline Yorkshire Tyne-Tees Television Plc & Group Director of Corporate Affairs \\
\hline
\end{tabular}

